\title{
Epstein-Barr (EB) virus infection in homosexual men in London
}

\author{
D H CRAWFORD,* I WELLER, † V ILIESCU,* AND D W WARA \\ From the University College and the Middlesex Hospital Medical Schools AIDS Research Group, ** the \\ *Department of Haematology and the ICRF Human Tumour Immunology Group, School of Medicine, \\ University College, London, the + Academic Department of Genitourinary Medicine, Middlesex Hospital \\ Medical School, London, and the $¥$ Department of Pediatrics, University of California, San Francisco, \\ California, USA
}

SUMMARY Twenty five homosexual men from London, 14 of whom had persistent lymphadenopathy and 11 of whom did not, were tested for immunity to Epstein-Barr (EB) virus. All yielded positive results to serological tests for the viral capsid antibody, and 11 had antibodies to the early antigen. Thirteen out of 17 were excreting virus into the saliva; culture of peripheral blood mononuclear cells from two of these patients showed no detectable regression induced by $\mathrm{T}$ cells that was specific to EB virus. No differences were found between the patients with and without lymphadenopathy. Peripheral blood B cells from six patients with hypergammaglobulinaemia were double stained for cytoplasmic immunoglobulin and EB viral nuclear antigen, and in all cases the activated B cells producing immunoglobulin did not contain EB nuclear antigen. Similarly, lymph node biopsy specimens from five patients showed no cells with EB nuclear antigen. These results indicate that although homosexual men have a high incidence of reactivated infection with EB virus, this viral infection is not the cause of the polyclonal activation of B cells seen in peripheral blood and is not implicated in the aetiology of the lymphadenopathy found in these men.

\section{Introduction}

The acquired immune deficiency syndrome (AIDS) was first described in 1981 with outbreaks of Pneumocystis carinii pneumonia and aggressive mucocutaneous Kaposi's sarcoma in young American homosexual men. ${ }^{1}$ Since then the number of cases has grown exponentially, and patients now include intravenous drug abusers, ${ }^{2}$ Haitians, ${ }^{3}$ and haemophiliacs. ${ }^{4}$ The syndrome has been extended to include a wide variety of viral, fungal, protozoal, and some bacterial opportunistic infections and other tumours such as non-Hodgkin's lymphomas. ${ }^{5}$ An underlying largely cellular immune deficiency has been described, which includes anergy to common skin recall antigens, impaired lymphocyte transformation, and lymphopaenia with depletion of the $\mathrm{T}$ helper (Th) subset and inversion of the ratio of $T$ helpers to $T$

**The AIDS research group includes M Adler, P C L Beverley, K McLellan, S Sutherland, R D Tedder, and the authors of this paper. Address for reprints: Dr D $\mathbf{H}$ Crawford, Faculty of Clinical Sciences, School of Medicine, University College, University Street, London WC1E 6JJ

Accepted for publication 15 February 1984 suppressors (Ts). ${ }^{6}$ Similar abnormalities of cell mediated immunity and inverted $\mathrm{Th} / \mathrm{Ts}$ ratios have been described in healthy homosexual men ${ }^{7}$ and haemophiliacs. ${ }^{8}$ An increasing number of cases of unexplained lymphadenopathy in homosexual men with and without non-specific symptoms has been reported. ${ }^{9}$ The exact relation of this lymphadenopathy syndrome to AIDS has yet to be established, but progression to AIDS has been described in around $10 \%$ of cases in the United States of America. ${ }^{10}$

Much attention has focused on the cellular immune deficiency, but patients with AIDS and some healthy homosexual men with or without lymphadenopathy also have abnormal humoral immunity. Hypergammaglobulinaemia ${ }^{7}$ associated with B cells that spontaneously produce immunoglobulin in vitro ${ }^{11}$ is found regularly, and autoimmune phenomena have been described. ${ }^{12}$ It has been suggested that these findings might be due to infection with Epstein-Barr (EB) virus, ${ }^{11} 13$ as it is known to infect $B$ lymphocytes in man ${ }^{14}$ stimulating them to produce immunoglobulin in vivo ${ }^{15}$ and in vitro. ${ }^{16}$ 
Primary infection with EB virus occurs in most people subclinically during childhood. If infection is delayed until adolescence, however, it may be clinically manifest as infectious mononucleosis. ${ }^{17}$ Primary infection results in an antibody response to the viral capsid antigen and EB viral nuclear antigen, which persist for life and can be found in $80-90 \%$ of adults worldwide, ${ }^{18}$ and a transient antibody response to the EB viral early antigen. ${ }^{19} \mathrm{~EB}$ virus is not completely eliminated from the body after primary infection. Thus spontaneous B cell lines carrying EB virus can be grown in vitro from lymphoid tissue, ${ }^{20}$ and infectious virus can be found intermittently in saliva or throat washings from most people with positive serological test results. ${ }^{21}$ This low grade infection is probably controlled, at least in part, by the cytotoxic $T$ cells present in the circulation which specifically lyse target cells infected with EB virus 22 in a human leucocyte antigen (HLA) $\mathrm{A}, \mathrm{B}$, and $\mathrm{C}$ restricted manner. ${ }^{23}$

In certain groups of immunosuppressed people there have been reports of increased isolation of EB virus from saliva, ${ }^{24}$ the spontaneous establishment of $B$ cell lines transformed by EB virus from peripheral blood lymphocytes, ${ }^{25}$ or both. This is probably due to a decrease in $\mathrm{T}$ cell immunity specific to EB virus, which allows increased numbers of cells infected with the virus to survive. ${ }^{26}$ This in turn leads to raised titres of serum antibodies to the viral capsid antigen and to the reappearance of antibodies to the viral early antigen. ${ }^{27}$ These groups of people also have an increased incidence of lymphomas, ${ }^{28}$ some of which are aetiologically associated with EB virus ${ }^{29}$ and are probably due to uncontrolled proliferation of infected $B$ cells in the absence of adequate $T$ cell immunity. ${ }^{26}$ Lymphomas associated with EB virus have also been reported in immunosuppressed homosexual men. ${ }^{5}$

In this study we compared the status of infection with EB virus in homosexual men with and without lymphodenopathy and investigated the role of the virus in the production of hypergammaglobulinaemia.

\section{Patients and methods}

STUDY POPULATION

We studied 14 exclusively homosexual men (average age $30 \cdot 5$ years, range 19-43) with unexplained lymphadenopathy in at least two anatomical sites other than inguinal, which had persisted for more than three months. Table I shows their clinical features. Eleven asymptomatic homosexual men (average age 30, range 21-42) with no history of illness or infection in the preceeding three months were studied concurrently. Both groups of patients were regularly attend- ing the department of genitourinary medicine at the Middlesex Hospital. Ten healthy heterosexual men were used as control subjects.

TABLE I Clinical features of 14 homosexual men with unexplained lymphadenopathy

\begin{tabular}{llll}
\hline $\begin{array}{l}\text { Case } \\
\text { No }\end{array}$ & Age & Symptoms & Other illness \\
\hline 1 & 33 & Night sweats & \\
2 & 43 & & \\
3 & 24 & Fatigue & \\
4 & 19 & Night sweats & \\
5 & 39 & Malaise & \\
6 & 37 & Fatigue and & \\
7 & 34 & night sweats & \\
8 & 29 & Fatigue & HBV and warts \\
9 & 21 & & HBV \\
10 & 28 & Night sweats & Herpes zoster \\
11 & 27 & Bruising & HBV and ITP \\
12 & 35 & 30 & \\
13 & 28 & & \\
14 &
\end{tabular}

$\mathrm{HBV}=$ Hepatitis $\mathrm{B}$ virus carrier $(\mathrm{HBe}$ antigen positive $)$; ITP = Idiopathic thrombocytopenic purpura.

SEROLOGY AND CULTURE OF SALIVA

Serum samples were assayed for antibodies to EB viral capsid antigen ${ }^{30}$ and EB viral early antigen using established methods. ${ }^{19}$

EB virus was isolated from saliva by diluting saliva $1 / 1$ with RPMI 1640 medium and centrifuging at $400 \times g$ for 10 minutes. The supernatant was filtered through a $0.45 \mu \mathrm{m}$ filter (Millipore, Harrow, Middlesex, United Kingdom) and stored in $1 \mathrm{ml}$ aliquots at $-70^{\circ} \mathrm{C}$. The thawed contents of one aliquot of each saliva specimen were added to a pellet of $2-4 \times 10^{6}$ mononuclear cells. prepared from human cord blood. The cells were resuspended, incubated at $37^{\circ} \mathrm{C}$ for one hour, washed in medium, and cultured at a concentration of $2 \times 10^{6} / \mathrm{ml}$ for three months. The cultures were fed regularly and observed for signs of transformation. All cell lines emerging were tested for the presence of EB nuclear antigen by the standard method. ${ }^{31}$

\section{STUDIES OF PERIPHERAL BLOOD} MONONUCLEAR CELLS

Peripheral blood mononuclear cells were obtained from $20-40 \mathrm{ml}$ heparinised blood by centrifugation on a Ficoll-Hypaque gradient. The cells were washed twice in medium before use.

Numbers of total leucocytes, total $T$ cells, $T$ suppressor/cytotoxic (Ts) cells, $T$ helper/inducer (Th) cells, and natural killer cell phenotypes were estimated using HLe-1, ${ }^{32}$ UCHT $1,{ }^{33}$ UCHT $4,{ }^{34}$ Leu 3a (Becton Dickinson, Sunnyvale, California, United States of America), and Leu 7 (Becton Dickinson) 
monoclonal antibodies respectively. The cells were stained by a conventional indirect immunofluorescence technique and analysed on a fluorescence activated cell sorter (FACS IV, Becton Dickinson). A four hour chromium release assay against K562 target cells was used to measure the natural killer cell activity of peripheral blood mononuclear cells.

\section{INFECTION OF CELLS WITH EB VIRUS AND CULTURE FOR REGRESSION ASSAY}

Pellets of $8 \times 10^{6}$ peripheral blood mononuclear cells were resuspended in $1 \mathrm{ml}$ supernatant culture medium from cell line B95-8,36 which contained EB virus and had been filtered through a $0.45 \mu \mathrm{m}$ filter and stored at $-70^{\circ} \mathrm{C}$. The cells were incubated at $37^{\circ} \mathrm{C}$ for one hour, pelleted, and resuspended in RPMI 1640 containing 100 IU penicillin and streptomycin, $2 \mathrm{mmol}$ glutamine, and $10 \%$ fetal calf serum. For the regression assay peripheral blood mononuclear cells infected with EB virus were cultured in $0.2 \mathrm{ml}$ volumes in microtest plate wells at concentrations of $2 \times 10^{6} \mathrm{ml}, 10^{6} / \mathrm{ml}, 0.5 \times 10^{6} / \mathrm{ml}$, and $0.25 \times 10^{6} / \mathrm{ml}$. Ten replicate cultures were plated at each cell concentration. Cyclosporin A 1 $\mathrm{mg} / \mathrm{l}$ was added to five cultures at each concentration to inhibit cytotoxic $\mathrm{T}$ cell activity. ${ }^{36}$ Cultures were placed in a $37^{\circ} \mathrm{C}$ incubator in an atmosphere of $5 \%$ carbon dioxide in air, and fed weekly by replacing half the culture medium without disturbing the cell layer. They were observed under an inverted microscope for four weeks for the appearance of proliferating foci of cells and the subsequent onset of regression.

E ROSETTING AND REMOVAL OF T CELLS FROM PERIPHERAL BLOOD MONONUCLEAR CELLS $E$ rosette positive and $E$ rosette depleted fractions of peripheral blood mononuclear cells were prepared and separated by the method of Kaplan and Clark. ${ }^{37}$

\section{CULTURE OF E ROSETTE NEGATIVE CELLS}

$E$ rosette negative cells from six patients known to have raised serum immunoglobulin concentrations were cultured at $10^{6} / \mathrm{ml}$ for seven days. The cells were then stained for cytoplasmic immunoglobulin, and the supernatant medium assayed for IgM, IgG, and IgA.

\section{IMMUNOGLOBULIN STAINING OF E ROSETTE NEGATIVE CELLS}

Cytospin preparations of fresh and cultured $E$ rosette negative cells were fixed in methanol and stained for cytoplasmic IgG, IgM, and IgA using rabbit antihuman antibodies conjugated with fluorescein (Dakopatts, Mercia-Brocades, Byfleet, Surrey, United Kingdom). When this staining procedure was doubled for EB nuclear antigen, antibodies conjugated with rhodamine (Dakopatts, MerciaBrocades) were added to the cell preparation with the second layer antibody.

IMMUNOGLOBULIN ASSAYS

Serum IgM, IgG, and IgA concentrations were measured by radial immunodiffusion. Concentrations of IgM, IgG, and IgA in culture supernatant media were measured by an enzyme linked immunoassay (ELIZA) technique.

STAINING LYMPH NODE BIOPSY SAMPLES FOR EB NUCLEAR ANTIGEN

Frozen sections cut from the snap frozen lymph node material were air dried, fixed in a mixture of equal volumes of acetone and methanol at $-20^{\circ} \mathrm{C}$, and stained for EB nuclear antigen. ${ }^{31}$

\section{Results}

SEROLOGY AND CULTURE OF SALIVA

Table II shows the results of serology tests and culture of saliva. The serum of all patients studied, both those with lymphadenopathy and asymptomatic homosexuals, was positive for IgG antibodies to viral capsid antigen with titres of $1 / 8$ to $1 / 4096$, the highest titres being in those with lymphadenopathy. No IgM antibodies to viral capsid antigen were found. Six of the 14 patients with lymphadenopathy and five of the 11 asymptomatic homosexuals also had detectable antibody to EB early antigen with titres of $1 / 4$ to $1 / 64$.

Random specimens of saliva from six out of eight patients with lymphadenopathy tested and from eight out of 10 asymptomatic homosexuals tested contained virus which transformed cord blood mononuclear cells. All cell lines generated expressed EB nuclear antigen.

\section{STUDIES OF PERIPHERAL BLOOD}

MONONUCLEAR CELLS

Table III shows numbers of lymphocytes and $\mathrm{T}$ cell subsets and concentrations of gammaglobulins in both groups of patients. Lymphopaenia $\left(<1.5 \times 10^{9}\right.$ lymphocytes/l) was present in three (Nos 1,13 , and 14) of the 14 patients with lymphadenopathy and in two of the 11 asymptomatic homosexuals. A low Th/Ts ratio $(<0.8)$ was present in nine out of 12 patients with lymphadenopathy and seven out of 10 asymptomatic homosexuals. In both groups this was generally due to an absolute decrease in numbers of Th cells. There were no overall differences in the natural killer cell phenotypes and natural killer cell killing between patients with lymphadenopathy, asymptomatic homosexuals, and the 15 healthy 
TABLE II Antibody to, regression associated with, and secretion in saliva of EB virus in patients with (1-14) and without (15-25) lymphadenopathy

\begin{tabular}{|c|c|c|c|c|}
\hline \multirow[b]{2}{*}{$\begin{array}{l}\text { Case } \\
\text { No }\end{array}$} & \multicolumn{2}{|c|}{ Titres of IgG antibody to: } & \multirow[b]{2}{*}{$\begin{array}{l}\text { Regression } \\
(\text { normal }=+(100 \%))\end{array}$} & \multirow[b]{2}{*}{$\begin{array}{l}\text { EB virus in saliva } \\
\text { (normal }=+(10 \%))\end{array}$} \\
\hline & $\begin{array}{l}\text { Viral capsid antigen } \\
\text { (normal }<1 / 512 \text { ) }\end{array}$ & $\begin{array}{l}\text { Early antigen } \\
\text { (normal }=- \text { ) }\end{array}$ & & \\
\hline $\begin{array}{r}1 \\
2 \\
3 \\
4 \\
5 \\
6 \\
7 \\
8 \\
9 \\
10 \\
11 \\
12 \\
13 \\
14\end{array}$ & $\begin{array}{l}1 / 32 \\
1 / 256 \\
1 / 2048 \\
1 / 512 \\
1 / 8 \\
1 / 512 \\
1 / 2048 \\
1 / 32 \\
1 / 128 \\
1 / 128 \\
1 / 256 \\
1 / 4096 \\
1 / 256 \\
1 / 128\end{array}$ & $\begin{array}{l}- \\
1 / 16 \\
1 / 8 \\
- \\
- \\
- \\
1 / 16 \\
- \\
- \\
1 / 16 \\
- \\
1 / 4 \\
1 / 16 \\
1 / 4\end{array}$ & $\begin{array}{l}+ \\
+ \\
\text { NT } \\
+ \\
+ \\
+ \\
+ \\
+ \\
+ \\
\text { NT } \\
\text { NT } \\
+ \\
\text { NT } \\
\text { NT }\end{array}$ & $\begin{array}{l}+ \\
+ \\
- \\
- \\
\text { NT } \\
+ \\
+ \\
+ \\
+ \\
\text { NT } \\
\text { NT } \\
\text { NT } \\
\text { NT } \\
\text { NT }\end{array}$ \\
\hline $\begin{array}{l}15 \\
16 \\
17 \\
18 \\
19 \\
20 \\
21 \\
22 \\
23 \\
24 \\
25\end{array}$ & $\begin{array}{l}1 / 16 \\
1 / 32 \\
1 / 8 \\
1 / 246 \\
1 / 128 \\
1 / 16 \\
1 / 128 \\
1 / 16 \\
1 / 32 \\
1 / 256 \\
1 / 32\end{array}$ & $\begin{array}{l}1 / 64 \\
- \\
- \\
- \\
1 / 8 \\
- \\
1 / 4 \\
1 / 8 \\
- \\
1 / 8 \\
-\end{array}$ & $\begin{array}{l}+ \\
+ \\
\text { NT } \\
- \\
\text { NT } \\
+ \\
+ \\
+ \\
+ \\
+ \\
+\end{array}$ & $\begin{array}{l}\text { NT } \\
+ \\
+ \\
- \\
+ \\
+ \\
+ \\
+ \\
+ \\
+ \\
-\end{array}$ \\
\hline
\end{tabular}

+ = positive; - = negative; $\mathrm{NT}=$ not tested.

heterosexual controls. Table III also shows that 10 of the 14 patients with lymphadenopathy and two of the 11 asymptomatic homosexuals had hypergammaglobulinaemia.

\section{REGRESSION IN CULTURES INFECTED WITH EB VIRUS}

Peripheral blood mononuclear cells infected with EB virus from all nine patients with lymphadenopathy tested and seven of the nine asymptomatic homosexuals tested showed normal regression. Two of the asymptomatic homosexuals (Nos 18 and 25) showed no evidence of regression (table II). Cell lines transformed by EB virus grew from all the cultures treated with cyclosporin $\mathbf{A}$.

\section{PRODUCTION OF IMMUNOGLOBULIN BY \\ E ROSETTE NEGATIVE CELLS}

Table IV shows the percentage of $E$ rosette negative cells that stained for cytoplasmic immunoglobulins or EB nuclear antigen before and after culture and that secreted immunoglobulin in the culture supernatant. Six out of 12 patients known to have raised serum immunoglobulin concentrations, five with

TABLE III Total lymphocytes and $T$ cell subsets and concentration of gammaglobulins in patients with and without lymphadenopathy

\begin{tabular}{|c|c|c|c|c|}
\hline & \multicolumn{2}{|c|}{$\begin{array}{l}\text { Patients with } \\
\text { lymphadenopathy }\end{array}$} & \multicolumn{2}{|l|}{$\begin{array}{l}\text { Asymptomatic } \\
\text { homosexuals }\end{array}$} \\
\hline & $\begin{array}{l}\text { No affected/ } \\
\text { No tested }\end{array}$ & Mean (SD) & $\begin{array}{l}\text { No affected/ } \\
\text { No tested }\end{array}$ & Mean (SD) \\
\hline \multirow{6}{*}{$\begin{array}{l}\text { Lymphopaemia } \\
\text { (lymphocytes }<1 \cdot 5 \times 109 / 1) \\
\text { Reduced T helpers } \\
\left(<0 \cdot 51 \times 10^{\circ} / \mathrm{l}\right)^{*} \\
\text { Increased T suppressors } \\
\left(>0 \cdot 98 \times 10^{9} / 1\right)^{*} \\
\text { Reduced Th/Ts ratio }(<0 \cdot 8) \\
\text { Hypergammaglobulinaemia: } \\
\text { Raised serum IgG }(>1700 \mathrm{~g} / \mathrm{l}) \\
\text { Raised serum IgA }(>350 \mathrm{~g} / \mathrm{l}) \\
\text { Raised serum IgM }(>210 \mathrm{~g} / \mathrm{l})\end{array}$} & $3 / 14$ & $1.90(0.82)$ & $2 / 11$ & $1.94(1.03)$ \\
\hline & $10 / 12$ & & $9 / 10$ & $0.37(0.24)$ \\
\hline & 10112 & (1) & $9 / 10$ & $0.31(0.24)$ \\
\hline & $\begin{array}{l}2 / 12 \\
9 / 12\end{array}$ & $\begin{array}{l}0.75(0.41) \\
0.59(0.38)\end{array}$ & $\begin{array}{l}3 / 10 \\
7 / 10\end{array}$ & $\begin{array}{l}0.84(0.50) \\
0.60(0.41)\end{array}$ \\
\hline & & & & \\
\hline & $\begin{array}{l}7 / 14 \\
3 / 14 \\
6 / 14\end{array}$ & $\begin{array}{l}1678(496) \\
221(64) \\
251(118)\end{array}$ & $\begin{array}{l}1 / 11 \\
1 / 11 \\
2 / 11\end{array}$ & $\begin{array}{c}1166(306) \\
187(83) \\
185(53)\end{array}$ \\
\hline
\end{tabular}

* Mean + SD in 15 healthy heterosexual control subjects; Th = T cell helpers; Ts = T cell suppressors. 
TABLE IV Percentage of $E$ rosette negative cells which stained for cytoplasmic IgM, IgG, IgA, or EB nuclear antigen and secreted immunoglobulin after culture for seven days

\begin{tabular}{|c|c|c|c|c|c|c|c|c|c|c|c|}
\hline \multirow[b]{3}{*}{ Case No } & \multicolumn{4}{|c|}{ Fresh $E$ rosette negative cells } & \multicolumn{7}{|c|}{$E$ rosette negative cells cultured for seven days } \\
\hline & \multicolumn{3}{|c|}{$\%$ cytoplasmic: } & \multirow{2}{*}{$\begin{array}{l}\% \text { EB } \\
\text { nuclear } \\
\text { antigen }\end{array}$} & \multicolumn{3}{|c|}{$\%$ cytoplasmic: } & \multirow{2}{*}{$\begin{array}{l}\% \text { EB } \\
\text { nuclear } \\
\text { antigen }\end{array}$} & \multirow{2}{*}{\multicolumn{3}{|c|}{$\begin{array}{l}\text { Immunoglobulin (mg/l, } \\
\text { in culture supernatant } \\
\text { IgM IgG IgA }\end{array}$}} \\
\hline & $\operatorname{Ig} M$ & $\operatorname{Ig} G$ & $\operatorname{Ig} A$ & & $\operatorname{Ig} M$ & $\operatorname{Ig} G$ & $\operatorname{Ig} A$ & & & & \\
\hline $\begin{array}{l}1 \\
11 \\
12 \\
13 \\
14 \\
24 \\
\text { Controls }\end{array}$ & $\begin{array}{r}<1 \\
<1 \\
1 \\
3 \\
2 \\
1 \\
<1\end{array}$ & $\begin{array}{r}2 \\
4 \\
2 \\
3 \\
5 \\
7 \\
<1\end{array}$ & $\begin{array}{l}1 \\
\text { NT } \\
1 \\
\text { NT } \\
2 \\
<1 \\
<1\end{array}$ & $\begin{array}{l}<1 \\
<1 \\
<1 \\
<1 \\
<1 \\
<1 \\
<1\end{array}$ & $\begin{array}{c}1 \\
<1 \\
\text { NT } \\
3 \\
5 \\
1 \\
<1\end{array}$ & $\begin{array}{c}2 \\
4 \\
\text { NT } \\
3 \\
5 \\
6 \\
<1\end{array}$ & $\begin{array}{l}1 \\
1 \\
\text { NT } \\
\text { NT } \\
\text { NT } \\
1 \\
<1\end{array}$ & $\begin{array}{l}<1 \\
<1 \\
\text { NT } \\
<1 \\
2^{*} \\
<1 \\
<1\end{array}$ & $\begin{array}{l}0 \cdot 16 \\
0 \cdot 03 \\
\text { NT } \\
0 \cdot 04 \\
2 \cdot 02 \\
0 \cdot 12 \\
<1\end{array}$ & $\begin{array}{c}55 \cdot 0 \\
4 \cdot 3 \\
\mathrm{NT} \\
8 \cdot 5 \\
51 \cdot 0 \\
53 \cdot 0 \\
<1\end{array}$ & $\begin{array}{c}0.35 \\
0 \cdot 54 \\
\text { NT } \\
0 \cdot 1 \\
36 \cdot 0 \\
8 \cdot 5 \\
<1\end{array}$ \\
\hline
\end{tabular}

NT $=$ not tested; $* 4 \%$ of cells with cytoplasmic immunoglobulin also contained EB nuclear antigen.

lymphadenopathy and one without, were found to have increased $(>1 \%)$ numbers of cells in fresh $E$ rosette negative cell preparations that contained cytoplasmic immunoglobulin. Up to $7 \%$ of cells stained for cytoplasmic IgG, whereas only $3 \%$ stained for cytoplasmic IgM and $2 \%$ for IgA. Using two colour immunofluorescence these cells containing immunoglobulin were shown to be uniformly negative for $E B$ nuclear antigen. Repeat staining of $E$ rosette negative cells after seven days' culture showed similar numbers of cells with cytoplasmic immunoglobulin, most of which contained IgG and were again negative for EB nuclear antigen. In one patient (No 14) an increase from $2 \%$ to $5 \%$ of cells with cytoplasmic IgM corresponded with finding $2 \%$ of cells with EB nuclear antigen. Freshly prepared and cultured $\mathrm{E}$ rosette negative cells from six heterosexual control subjects had immunoglobulin in less than $1 \%$ and EB nuclear antigen in none. When these cells were deliberately infected with EB virus and cultured for seven days, $72-100 \%$ of the cells with immunoglobulin also contained EB nuclear antigen. Immunoglobulin concentrations in the seven day supernatant medium from cultured $E$ rosette negative cells were: IgG $4 \cdot 3-53 \mathrm{mg} / \mathrm{l}$, IgM $0 \cdot 03-2 \cdot 02 \mathrm{mg} / \mathrm{l}$, and IgA $0 \cdot 01-8 \cdot 5 \mathrm{mg} / \mathrm{l}$. Those from the six control cultures were all less than $1 \mathrm{mg} / \mathrm{l}$ for each class of immunoglobulins.

\section{LYMPH NODE BIOPSIES}

Four of the five lymph node biopsy specimens studied showed histological findings consistent with a non-specific lymphadenitis. In the one remaining lymph node there were no germinal centres, and general depletion of lymphoid cells from the B cell region was associated with deposits of hyaline material. Staining these lymph node biopsies gave uniformly negative results for EB nuclear antigen.

\section{Discussion}

We studied immunity to EB virus in 25 homosexual men in London with and without lymphadenopathy. All 25 patients had antibodies to viral caspid antigen. The high titre of such antibodies found in some patients, taken with the high incidence of detectable antibodies to early antigen and isolation of the virus in saliva (table II), indicate that this group of patients has a high incidence of reactivated EB virus infection. These findings suggest that the patients have increased numbers of infected cells in the body, due either to constant reinfection with the virus or to a decrease in immunosurveillance specific to EB virus, which allows increased numbers of infected cells to survive. Our findings of non-specific immune abnormality in most of the patients, as indicated by a reversed $\mathrm{Th} / \mathrm{Ts}$ ratio (table III), and no detectable regression induced by $T$ cells specific to $E B$ virus in two patients (table II) would lend support to the latter theory. Raised titres of antibody to viral capsid antigen and early antigen have previously been reported in patients with AIDS. ${ }^{3}$ In other groups of immunosuppressed people (such as recipients of renal transplants, ${ }^{24} 26$ and patients with ataxia telangiectasia, ${ }^{27}$ rheumatoid arthritis, ${ }^{38}$ and multiple sclerosis $^{39}$ ) increased incidence of salivary secretion of the virus and the absence of regression have also been noted. These findings do not signify a role for EB virus in the aetiology of the disease, but reactivation of infection with EB virus due to immunosuppression associated with the disease process itself. It is interesting that we could find no difference between the two groups of patients studied with regard to immunity to EB virus, and that even in the apparently healthy group most men showed reactivation of infection.

EB virus is a polyclonal activator of B lymphocytes, ${ }^{16}$ and $B$ cells expressing both EB nuclear 
antigen and cytoplasmic immunoglobulin have been found in the circulation early in infectious mononucleosis. ${ }^{15}$ Thus it has been postulated that the polyclonal activation of B cells seen in some homosexual men and patients with AIDS is due to reactivated EB virus infection. ${ }^{11} 13$ We have shown that when $E$ rosette negative cells from normal people are polyclonally activated by EB virus in vitro most $(72-100 \%)$ of the cells producing immunoglobulin also contained EB nuclear antigen, and that the predominant cytoplasmic immunoglobulin was IgM. Conversely, when fresh $\mathrm{E}$ rosette negative cells from six homosexual men with hypergammaglobulinaemia were examined, IgG was the predominant cytoplasmic immunoglobulin and the cells did not contain EB nuclear antigen (table IV). Furthermore, after seven days' culture, E rosette negative cells from five of the six patients maintained IgG as the major cytoplasmic immunoglobulin and remained negative for EB nuclear antigen. IgG was also the predominant immunoglobulin in the culture supernatant. These results indicate that the cells containing immunoglobulin were not activated by EB virus. E rosette negative cells from one patient after seven days' culture showed $2 \%$ of cells containing EB nuclear antigen, which indicated the emergence of a spontaneous B cell line transformed by EB virus. This finding was mirrored by an increase in IgM in the culture supernatant and in cells containing cytoplasmic IgM (table IV), and shows that EB virus stimulates a different subpopulation of B cells from those activated in vivo in this patient.

Finally, we have recently examined the cells containing cytoplasmic immunoglobulin in the peripheral blood of a homosexual man with hypergammaglobulinaemia and a widespread lymphoma consisting of cells expressing EB nuclear antigen. Even in this case IgG was the predominant immunoglobulin in the cells of the peripheral blood, and they did not contain EB nuclear antigen. Thus there was no association between the proliferating tumour cells containing EB nuclear antigen and the activated $B$ cells in the peripheral blood. Lymph node biopsy specimens from five patients with lymphodenopathy were also negative for EB nuclear antigen.

From these findings we conclude that the in vivo stimulation of peripheral blood B lymphocytes to produce immunoglobulin and the aetiology of lymphadenopathy in homosexual men are not affected by EB virus. It follows that some other as yet unidentified polyclonal activator(s) must be present in these patients. In this context it has been shown that antigenic material from the rectal lumen is absorbed into the systemic circulation leading to the production of antisperm and anti-HLA antibodies. ${ }^{40}$ Thus it may be that some of this material, in particular polysaccharide from the bacterial cell wall, activates B cells. Experiments are at present under way in our laboratory to elucidate this point.

We thank Dr R Tedder for the use of his laboratory.

\section{References}

1. Centers for Disease Control task force on Kaposi's sarcoma. Epidemiological aspects of the current outbreak of Kaposi's sarcoma and opportunistic infections. N Engl J Med 1982; 306: 248-52.

2. Moll B, Emeson EE, Small CB, Friedland GH, Klein RS, Spigland I. Inverted ratios of inducer to suppressor T-lymphocyte subsets in drug abusers with opportunistic infections. Clin Immunol Immunopathol 1982; 25:417-23.

3. Pitchenik AE, Fischl MW, Dickinson GM, et al. Opportunistic infections and Kaposi's sarcoma among Haitians: evidence of a new acquired immunodeficiency state. Ann Intern Med 1983; 98:277-83.

4. Centers for Disease Control. Update on acquired immune deficiency syndrome (AIDS) among patients with hemophilia A. $M M W R$ 1982;31:644-52.

5. Ziegler JL, Drew WL, Miner RC, et al. Outbreak of Burkittslike lymphoma in homosexual men. Lancet 1982; ii:631-3.

6. Fauci AS. The syndrome of Kaposi's sarcoma and opportunistic infections. An epidemiologically restricted disorder of immunoregulation (Editorial). Ann Intern Med 1982;96:777-9.

7. Stahl RE, Friedman-Kien A, Dubin R, Marmor M, ZollaPazner S. Immunologic abnormalities in homosexual men. Relationship to Kaposi's sarcoma. Am J Med 1982; 73:171-8.

8. Lederman MM, Ratnoff OD, Scillian JJ, Jones PK, Schacter B. Impaired cell-mediated immunity in patients with classical hemophilia. N Engl J Med 1983; 308: 79-83.

9. Centers for Disease Control. Persistent generalised lymphadenopathy among homosexual males. $M M W R$ 1982;31: 249-51.

10. Fernandez R, Mouradian J, Metrolea C, Davis J. The prognostic value of histopathology in persistent generalised lymphadenopathy in homosexual men. $N$ Engl $J$ Med 1983; 309: 185-6.

11. Lane HC, Masur H, Edgar LC, Whalen G, Rook AH, Fauci AS. Abnormalities of B-cell activation and immunoregulation in patients with acquired immunodeficiency syndrome. $N E n g l$ J Med 1983;309:453-8.

12. Morris L, Distenfeld A, Amarosi E, Karpatkin S. Autoimmune thrombocytopenic purpura in homosexual men. Ann Intern Med 1982;96:714-7.

13. Groopman JE, Gottlien MS. Acquired immunodeficiency syndrome (AIDS): the widening gyre. Nature 1983;303:575-6

14. Pattengale $P K$, Smith RW, Gerber $P$. Selective transformation of B lymphocytes by EB virus. Lancet 1973; ii:93-4.

15. Robinson JE, Smith D, Niederman J. Plasmacytic differentiation of circulating Epstein-Barr virus-infected B lymphocytes during acute infectious mononucleosis. $J$ Exp Med 1981; 153: 235-44.

16. Rosen A, Gergely P, Jondal M, Klein G, Britton S. Polyclonal Ig production after Epstein-Barr virus infection of human lymphocytes in vitro. Nature 1977; 267:52-4.

17. Miller S. Epstein-Barr herpes virus and infectious mononucleosis. Prog Med Virol 1975; 20:84-112.

18. Hewetson JF, Rocchi G, Henle W, Henle G. Neutralizing antibodies to Epstein-Barr virus in healthy populations and patients with infectious mononucleosis. J Infect Dis 1973; 128: 283-9.

19. Henle W, Henle G, Zajac BA, Pearson G, Waubke R, Scriba $M$. Differential reactivity of human serums with early antigen induced by Epstein-Barr virus. Science 1970; 169: 188-90.

20. Nilsson K, Klein G, Henle W, Henle G. The establishment of lymphoblastoid lines from adult and foetal human lymphoid cells and its dependence on EBV. Int J Cancer 1971;8:443-50.

21. Gerber P, Nonoyama M, Lucas S, Perlin E, Goldstein LI. Ora excretion of Epstein-Barr virus by healthy subjects and patients with infectious mononucleosis. Lancet 1972; ii:988-9. 
22. Moss DJ, Rickinson AB, Pope JH. Long-term T-cell-mediated immunity to Epstein-Barr virus in man. I. Complete regression of virus-induced transformation in cultures of seropositive donor leucocytes. Int J Cancer 1978; 22:662-8.

23. Rickinson AB, Wallace LE, Epstein MA. HLA-restricted T-cell recognition of Epstein-Barr virus-infected B cells. Nature 1980;283:865-7.

24. Strauch B, Siegel N, Andress LL, Miller G. Oropharyngeal excretion of Epstein-Barr virus by renal transplant recipients and other patients treated with immunosuppressive drugs. Lancet 1974; i: 234-7.

25. Crawford DH, Edwards JMB, Sweny P, Janossy G, Hoffbrand AV. Long term T-cell-mediated immunity to Epstein-Barr virus in renal-allograft recipients receiving cyclosporin-A. Lancet 1981; i: 10-2.

26. Crawford DH, Edwards JMB, Sweny P, Hoffbrand AV, Janossy G. Studies on long-term T-cell-mediated immunity to Epstein-Barr virus in immunosuppressed renal allograft recipients. Int J Cancer 1981;28:705-9.

27. Henle W, Henle G. Consequences of persistent Epstein-Barr virus infections. Cold Spring Harbour Symposium. Viruses in naturally occurring cancers. Berlin, New York: Springer Verlag, 1980; 7:3-8.

28. Penn I. Tumour incidence in human allograft recipients. Transplant Proc 1979; 11: 1047-51.

29. Crawford DH, Thomas JA, Janossy G, et al. Epstein-Barr virus nuclear antigen positive lymphoma after cyclosporin-A treatment in patient with renal allograft. Lancet 1980; i: 1355-6.

30. Henle G, Henle W. Immunofluorescence in cells derived from Burkitt's lymphoma. J Bacteriol 1966;91:1248-56.

31. Reedman BM, Klein G. Cellular localisation of an Epstein-Barr virus (EBV)-associated complement-fixing antigen in producer and non-producer lymphoblastoid cell lines. Int $\boldsymbol{J}$ Cancer 1973; 11:499-520.
32. Beverley P. Production and use of monoclonal antibodies in transplantation immunology. Proceedings of XI Internationa Course on Transplantation and Clinical Immunology. Amsterdam: Excerpta Medica, 1980;87-94.

33. Beverley PCL, Callard RE. Distinctive functiona characteristics of human ' $T$ ' lymphocytes defined by $E$ rosetting or monoclonal anti-T cell antibody. Eur J Immunol 1981;11:329-34.

34. Beverley PCL. The application of monoclonal antibodies to the typing and isolation of lymphoreticular cells. Proceedings of the Royal Society of Edinburgh 1982;81B:221-32.

35. Miller G, Shope T, Lisco H, Stitt D, Lipman M. Epstein-Barr virus: transformation cytopathic changes and viral antigens in squirrel monkey and marmoset leucocytes. Proc Natl Acad Sci USA 1972; 69:383-7.

36. Crawford DH. Lymphomas after cyclosporin A treatment. In: Touraine JL, Traeger J, Betnel $\mathrm{H}$, et al, eds. Transplantation and clinical immunology XIII. Lymphomas after cyclosporin A treatment. Amsterdam: Excerpta Medica, 1981;48-52.

37. Kaplan ME, Clark C. An improved rosetting assay for detection of human T lymphocytes. J Immunol Methods 1974; 5:131-5.

38. Gaston JSH, Rickinson AB, Epstein MA. Epstein Barr virusspecific cytotoxic $T$ cell responses in rheumatoid arthritis. Rheumatol Int 1982; 2: 155-9.

39. Craig JC, Haire M, Millar JH, Fraser KB, Merrett JD, Immunological control of Epstein-Barr virus-transformed lymphocytes in multiple sclerosis. Clin Immunol Immunopathol 1983; 1:86-93.

40. Sonnabend J, Witkin SS, Purtilo DT. Acquired immunodeficiency syndrome, opportunistic infections and malignancies in male homosexuals. A hypothesis of etiologic factors in pathogenesis. JAMA 1983;249:2370-4 